\title{
INTRODUCTION: COLONIAL GRIEVANCES, JUSTICE AND RECONCILIATION
}

\author{
TOON VAN MEIJL \\ Radboud University Nijmegen \\ MICHAEL GOLDSMITH \\ University of Waikato
}

On the morning of Wednesday, 13 February 2008, we were standing alongside thousands of others in the grounds of the Australian parliamentary complex in Canberra (Gemes 2008). The fortuitous timing of a conference that had brought us from the Netherlands and New Zealand, respectively, had unexpectedly also given us the opportunity to attend the apology to indigenous Australians that newly elected Prime Minister Kevin Rudd had promised a few months before. John Howard, the previous Prime Minister, whose government had been replaced by Rudd's Labor administration, had stubbornly refused to utter such an apology. This controversial issue in Australian politics had first been tabled in Parliament in 1997 after a Federal Commission of Enquiry into the separation of Aboriginal and Torres Strait Islander children from their families, also known as the Stolen Generations, recommended that the Australian Parliament offer official apologies and officially acknowledge the responsibility of their predecessors for the laws, policies and practices of forcible removal. Howard, however, had consistently rejected what he called a "black armband view of history". Rudd, by contrast, had made it one of his campaign pledges in 2007. Knowing the historic significance of the occasion, we were determined to join the throng.

At one end of the long sward on which we were standing was the old Parliament House, where the Aboriginal Embassy had been located since 1972, and at the other end, on the top of a low hill, stood the new Parliament House, where Rudd's speech would be delivered and broadcast. Earlier, we had walked onto the grounds past the scattered encampments of Aborigines who had been arriving from around the country over the previous days. Despite their highly visible presence, they were outnumbered by nonAboriginal people of all ages and occupations, among them middle-aged couples in sensible bush hats and sturdy shoes, young professionals and civil servants in suits, and university students in black outfits covered in badges. Some waved newly purchased Aboriginal and Torres Strait Islander flags, some waved Australian flags, some waved both. 
Halfway up the gentle slope to the new Parliament House stood a soundstage with a large screen display on either side. As we waited, the screens remained blank except for the still caption "National Day of Apology". In the nearby enclosure of the Australian Broadcasting Corporation, two announcers on stools faced the cameras and chatted into their microphones. Shortly before $9.00 \mathrm{am}$, the screens sprang to life and we saw parliamentarians entering the chamber of the lower house to the sound of sporadic applause. The newly appointed Speaker, Harry Jenkins, launched proceedings with a recital of the Lord's Prayer. Rudd then rose to give his speech, which began with the apology:

Today we honour the Indigenous peoples of this land, the oldest continuing cultures in human history.

We reflect on their past mistreatment.

We reflect in particular on the mistreatment of those who were Stolen Generations - this blemished chapter in our nation's history.

The time has now come for the nation to turn a new page in Australia's history by righting the wrongs of the past and so moving forward with confidence to the future.

We apologise for the laws and policies of successive Parliaments and governments that have inflicted profound grief, suffering and loss on these our fellow Australians.

We apologise especially for the removal of Aboriginal and Torres Strait Islander children from their families, their communities and their country.

For the pain, suffering and hurt of these Stolen Generations, their descendants and for their families left behind, we say sorry.

To the mothers and the fathers, the brothers and the sisters, for the breaking up of families and communities, we say sorry.

And for the indignity and degradation thus inflicted on a proud people and a proud culture, we say sorry.

We the Parliament of Australia respectfully request that this apology be received in the spirit in which it is offered as part of the healing of the nation.

For the future we take heart; resolving that this new page in the history of our great continent can now be written. 
We today take this first step by acknowledging the past and laying claim to a future that embraces all Australians.

A future where this Parliament resolves that the injustices of the past must never, never happen again.

A future where we harness the determination of all Australians, Indigenous and non-Indigenous, to close the gap that lies between us in life expectancy, educational achievement and economic opportunity.

A future where we embrace the possibility of new solutions to enduring problems where old approaches have failed.

A future based on mutual respect, mutual resolve and mutual responsibility.

A future where all Australians, whatever their origins, are truly equal partners, with equal opportunities and with an equal stake in shaping the next chapter in the history of this great country, Australia. (Rudd 2008)

On each of the three occasions that Rudd said the word "sorry", the crowd broke into applause. It was a truly emotional event for Aboriginal attendants, many of whom were moved to tears (see Augoustinos, Hastie and Wright 2011). But not everyone present was convinced. When the Prime Minister mentioned the taking of children, an Aboriginal man yelled "Yeah? Who's your father?" and raised the small cardboard sign that he was clutching. One side read "Quarantine Racism Not Welfare" and the other "No Racist Intervention". These were references to a heavy-handed and intrusive policy launched by the Federal Government in Aboriginal communities in the Northern Territory during the months leading up to the election. The intervention involved a package of changes to welfare provision, law enforcement, land tenure and other measures, including alcohol restrictions, pornography filters, deployment of additional police, enforced school attendance, compulsory health checks, suspension of the permit system and the overall intensification of governance through the appointment of more government managers. Many commentators argued that this policy continued and even intensified the paternalism and discrimination of the past. After the election, however, instead of countermanding his predecessor's policy, Rudd had adopted a wait-and-see approach in order to allow the merits of the intervention to be assessed. Was this continuation of a John Howard-style approach a sign that the long-awaited apology would play a purely symbolic role, garnering political credit without changing the substance of race relations or sacrificing any of White Australia's privilege? 
Indeed, the full-length speech that followed the apology could be said to fall short of the breakthrough that the moment demanded (see Harris, Grainger and Mullany 2006). Five times Rudd announced a strategy for "closing the gap" between Indigenous and non-Indigenous Australians, a strategy that was based on some questionable premises. It subjected cultural differences to a future of assimilation, while at the same time depending on a model of cultural deficit in which indigeneity was treated both as a pathology and as the vehicle of its own improvement (Kowal 2008). The contradiction in such an idea was that it both constructed the gap as a social reality and then tried to abolish its effects.

Across the Tasman Sea, the New Zealand Labour government elected in 1999 had adopted the mantra of "closing the gaps" only to retreat from it in some confusion under a triple assault from some monocultural conservatives, who resented any implications of "special treatment" for Māori, from some commentators who objected to a policy based on alleged cultural differences, and from some progressive analysts, who attributed inequalities between Māori and the non-Māori or Pākehā majority to secular processes of class stratification rather than to a purely ethnic division.

Rudd's speech ended to a standing ovation in the House (at least from his Labor colleagues) and a wave of applause from those of us outside watching. The Leader of the Opposition, Brendan Nelson, then exercised his right of reply. He briefly grabbed back the moral high ground with a few words of acknowledgement to the local Ngunawal people (a nicety that Rudd had overlooked), but soon drew the ire of the crowd with his attempts to defend the indefensible policies of the previous administration. When he broached the topic of squalor and sexual abuse in Aboriginal communities, boos erupted. Near us, an Aboriginal woman shouted, "Our grandmothers were fucking raped by the colonisers!" As the speech went on, most people in the crowd turned their backs to the screens and slow handclapped the speaker.

There is no need to emphasise that the historic apology offered to the Stolen Generations of Aboriginal and Torres Strait Islander people by the Australian Prime Minister Kevin Rudd cannot be understood in isolation from similar events happening around the world (Short 2008). These began with the Truth and Reconciliation Commission chaired by Bishop Desmond Tutu in South Africa, who was guided by the Christian concept that "there is no future without forgiveness" when he examined the country's history of apartheid. Many other countries with a violent history characterised by ethnic strife have subsequently followed this attempt to address the grievances of peoples who were formerly colonised or otherwise dominated by ethnic aliens. Paradoxically, however, these colonial grievances seem to have proliferated, or at least to have become more strongly voiced, after decolonisation was 
completed in the 1980s. This applies to almost all culture areas in the world, including the Pacific.

Throughout the Pacific region, too, strong anti-colonial sentiments are expressed, but these often seem to be spurred just as much by the process of decolonisation as by the practices that colonial regimes engaged in during earlier peaks of power. In most situations, too, counter-colonial resistance is intertwined with neo-colonial connections, usually economic in nature, which continue unabated in spite of the trend towards political independence in recent decades. In nation-states with significant minorities of indigenous origin, public debates revolve around demands for the return of sovereignty from colonial settlers and their descendants. For these reasons, as Otto and Thomas (1997: 4) argued, it is difficult to talk about a straightforward "colonial aftermath" in the Pacific.

The articles in this special issue are concerned with these colonial and postcolonial grievances and the question of how to address contemporary forms of counter-hegemonic, including counter-colonial, resistance in the Pacific. We have two main aims: first, to show how colonial grievances vary across certain Pacific societies and, second, to discuss the various strategies that may be developed to seek justice and to bring about reconciliation (if these can be achieved).

Colonial grievances are expressed in a variety of different historical conditions. Indigenous minorities in settler states, notably in New Zealand, Australia and Hawai' $i$, are demanding the restoration of sovereignty and the return of properties that were dispossessed in the colonial past (see the article in this issue by Toon van Meijl on New Zealand). Postcolonial nation-states that have obtained independence relatively recently, particularly small island states in Polynesia, but also Papua New Guinea, for example, continue to remind their former colonisers of their responsibility to redress economic difficulties that are blamed on the history of colonisation (see the article by Goldsmith on Tuvalu). The ongoing debate about the international exploitation of natural resources in the Pacific, especially in Melanesia, although not restricted to colonialism and its immediate consequences, is deeply rooted in its history (see the article by Daniele Moretti on grievances in Morobe Province, Papua New Guinea). Colonialism has also left a whole range of other problematic legacies, for example, the ethnic tension that takes somewhat different forms in Fiji, the Solomon Islands, New Zealand, Australia and Hawai' $i$. And there are other equally important grievances that the contributors to this issue have not addressed, such as requests for the repatriation of cultural heritage held in trust by former colonisers, e.g., in ethnographic museums (Barkan and Bush 2002, Busse 2008, Van Meijl 2009). 
Political discussions in these divergent circumstances generally revolve around the issue of who is responsible for the harm that colonialism inflicted and the related issue of who was harmed. These lead, in turn, to the further questions of how the perpetrators of harm are identified, how deserving cases of justice and reconciliation are constructed, and how the relevant discourses of responsibility respond to historical, political and cultural change. The casestudies brought together in this issue share a concern with these challenging questions. Before commenting on the contributions to this issue, however, we would first like to explore the context of the debate even further by looking at the persistence of colonial grievances in the postcolonial Pacific.

\section{"HOLOCAUST" DISCOURSE}

A statement in August 2000 by Tariana Turia, who was then the Associate Maori Affairs Minister in the Labour Government of New Zealand, dramatically highlights contemporary grievances about the colonial legacy of at least some Pacific peoples. In a speech to the New Zealand Psychological Society about what she called "Post Colonial Traumatic Stress Disorder", she was reported to have said: "What seems to not have received... attention is the holocaust suffered by indigenous people including Māori as a result of colonial contact and behaviour" (New Zealand Herald, 31 August 2000; see also Turia 2000a, 2000b).

Her reference to a holocaust actually echoed a prior report by the Waitangi Tribunal, the body established in 1975 to inquire into Māori grievances stemming from breaches of the 1840 Treaty of Waitangi. However, The Taranaki Report (NZWT 1996) had used the term without generating anything like the reaction Turia's speech was to provoke four years later. Presumably her public profile and the political climate, including the Labour election victory of 1999, had raised the ante. The New Zealand Labour Party has historically claimed to deliver greater political and economic advancement for Māori than its main rivals, so for one of its most prominent Māori members at the time to claim that colonialism continued to have ugly and lingering consequences was to question those achievements and perhaps even Labour's commitment to Māori causes.

In any event, the speech caused a public outcry in New Zealand. We suggest that it did so for two main reasons. First, since it implicitly compared Māori experiences during colonialism to the genocide of Jews, gypsies and others during the Nazi era, some commentators felt that the latter epoch had been devalued. Second, it suggested that Māori people had been deliberately killed by earlier generations of colonial settlers, not only during the New Zealand Wars of the 1860s and 1870s, but also by the introduction of new diseases, the undermining of Māori social-political structure and the annexation of 
native land. Non-Māori colleagues in cabinet therefore forced Mrs Turia to apologise, which in turn led the chief executive of the New Zealand Maori Council to compare the pressing demand for Mrs Turia to apologise to Adolf Hitler's practices of "gagging the Jews and burning them off" (New Zealand Herald, 8 September 2000). Mason Durie, a psychiatrist and professor of Māori Studies and as such an influential and respected Māori spokesperson, commented that, although the term holocaust might grate on New Zealand's national pride, the Māori population did decline from 200,000 in 1840 to 42,000 in 1900 , which in his opinion made it "pretty close to a holocaust" (Gifford 2000: 3). Public debate in New Zealand subsequently spiralled into a clash of interpretations over 19th-century history that could in many instances be likened to a politics of holocaust denial (Goldsmith 2002).

The New Zealand furore might at first glance seem to have only local relevance, but in fact similar kinds of analyses and debates (drawing on terms such as genocide as well as holocaust) are not unusual in Australia and the wider Pacific (see, for example, Bingham 1996, Bushnell 1993, Van Krieken 2004, Wing and King 2005). Further afield, the notion of holocaust has been applied for decades to the Armenian experience under Turkish rule and in more recent decades to Cambodia and Rwanda. Retrospectively the concept has become a powerful frame for the understanding of the devastation caused by the post-Columbian intrusion of the Old World into the New World of the Americas.

Why has the language of holocaust found new currency in interpretations of the past and the present? Andreas Huyssen (2000) suggests we can now speak of a globalisation of holocaust discourse and explains the expansion of this discourse in two different ways. First, he refers to the rise of new memory discourses in the wake of decolonisation after the 1960s (see, for example, Bal, Crewe and Spitzer 1999). Both newly independent countries and new social movements seeking to restructure the distribution of power in former empires began searching for alternative and revisionist histories (Stein 1998). In the new era the past was increasingly recodified after the end of modernism, which not infrequently coincided with the end of colonialism (De L'Estoile 2008). Second, in the early 1980s these memory discourses proliferated in Europe and the United States, where they were triggered by a popular television series about the Holocaust, as well as by media attention paid to 40th and 50th anniversaries of events in the history of the Third Reich, such as Hitler's rise to power in 1933 and the end of the Second World War in 1945 (Huyssen 2000: 22-3). At the same time, recent revisionist histories have often been accompanied by multiple statements about the end of history (Fukuyama 1992, but see Fukuyama 2011), the death of the subject (Foucault 1966) and the end of meta-narratives (Lyotard 1979). 
The recurrence of genocidal politics in Rwanda, Bosnia and Kosovo in the 1990s, and in Darfur more recently, have kept the Holocaust memory alive and extended it past its original reference point. The revival of these memories enabled the concept to become a metaphor for the 20th century as a whole and to some extent even of the entire project of the Enlightenment. One of the ramifications of this so-called globalisation of holocaust discourse is that memory emerged as a key concern in international politics. Whereas the future was privileged in the present of modernism, the past suddenly cast a dark shadow over the present in the last decades of the millennium. Beliefs in the emergence of an enlightened future were replaced by a perception of the present as deeply rooted in an evil past, characterised by racial oppression and ethnic cleansing. This totalising re-interpretation of the Holocaust that resulted in renewed attention for the memory of the past, however, is paradoxically accompanied by a particularisation or localisation of the Holocaust, as testified, for example, by the comparison to Māori colonial experiences. It is precisely the representation of the Holocaust as a universal trope for the failure of modernity, and its belief in progress during the colonial era, that allows memories of dark histories to link up to specific local situations that are historically distant and politically distinct from the original event. In the transnational dimension of memory discourses the Holocaust thus no longer functions as an index of the specific historical event but becomes a metaphor for other traumatic histories and memories (Huyssen 2000: 24, see also Alexander, Eyerman, Giesen et al. 2004, Salzman 2005).

\section{THE QUESTION OF CULPABILITY}

Renewed attention to memories of traumatic histories of genocides or colonial violence in a broad sense has raised the question of culpability. Demands for apologies and a more fundamental redress of historical injustices have not only emerged in the Pacific, but are again part of a worldwide tendency (Barkan and Karn 2006). As mentioned before, truth commissions have been set up to investigate the practice of apartheid in South Africa and human rights abuses during the civil war in Guatemala. In Rwanda and former Yugoslavia war crimes tribunals have likewise attempted to identify culpability and to repair the social consequences of violent ethnic conflicts. Beyond these examples of countries seeking the truth after internal hostilities, the question of culpability has also been raised in other cases of historical injustices. Some of these have international dimensions, involving offences against foreign citizens (e.g., Japanese reparations to Korean "comfort women" and to Dutch colonists in Indonesia for their detention during the Second World War, but also Dutch war crimes against Indonesian citizens who had claimed independence from the Netherlands) or crimes associated with the deportation of people from one 
country to another (e.g., German reparations to Jews or demands for reparations for slavery in the United States and elsewhere). Other instances involved offences against social groupings within states, such as the U.S. government's compensation of Japanese Americans for internment during the Second World War, and, of course, the recent recognition of the dramatic consequences of the dispossession and enforced assimilation of indigenous peoples in Australia, Canada and New Zealand (see Elkins and Pedersen 2005).

The Indian anthropologist Nandini Sundar (2004: 147) has lately examined the question why the redress of historical injustices has become important at this moment in time, more than half a century after the Nuremberg Trials first placed the issue of retribution on the international agenda. On the one hand, she refers to scholars attributing the rise of truth and reconciliation commissions, reparations and state apologies to the emergence of a new international morality. They argue that the acceptance of culpability has usually followed an increase in respect for minority voices and the rise of human rights discourse since the end of the Second World War. In academic reflections the current wave of retributive justice is often also related to the gradual transition from authoritarianism to democracy (Fukuyama 1992). On the other hand, however, Sundar also draws attention to the relationship between the contemporary culture of apologising for historical wrongdoings and the political legitimisation of a world order marked by growing inequality rather than by evolving standards of justice, morality and respect. After all, globalisation is clearly reinforcing economic disparities between the West and the Rest, and the number of violent conflicts has actually increased since the end of the Cold War. In this context, Sundar's reflections resonate with Huyssen's argument that redress and apologies articulate a crisis in modernity with its "trust in progress" and "some telos of history" (Huyssen 2000: 36). In recent times, the history of the 20th century is increasingly believed to have undermined the teleology of development, and the portrayal of retributive justice as part of a new international morality thus becomes part of a "selfcongratulatory liberal understanding that allows real and ongoing inequalities and injustices to go unchallenged" (Sundar 2004: 148).

Indeed, implicitly the message of apologies and the (partial) settlement of historical injustices is that the bad behaviour is a thing of the past and that the present is no longer characterised by practices that warrant prosecutions or the establishment of tribunals whose task it is to investigate all kinds of human rights violations. For the time being, however, Sundar's suggestion remains the subject of debate. Whether the so-called new international morality genuinely implies the recognition of cultural and economic differences at global and local levels, or whether the discourse of apologies must be equated with the self-serving prejudice of powerful states or rulers, can only 
be established through a comparative examination of the process of settling historical grievances. That precisely is the main aim of this collection of essays: to compare and contrast demands for apologies, restitution claims and reparations in a variety of Pacific societies, including the question of why and how some groups have their demands taken more seriously than others. In addition, each essay grapples with the ultimate goal of whether and how the settlement of colonial grievances can be achieved. Not infrequently, this has been addressed under the rubric of reconciliation, but that, too, has become a rather ambiguous notion over the past decade.

\section{RECONCILIATION}

Ideally, reconciliation is the logical outcome of any process that aims at settling colonial grievances or other types of historical injustices. After the question of culpability has been addressed, apologies offered and reparations agreed upon, reconciliation is normally supposed to take place. In the aftermath of violent conflicts or protracted periods of subordination, however, reconciliation is truly difficult to achieve. It has also become apparent that reconciliation evokes different connotations in different circumstances. This awareness recently generated a discussion about the meaning of the concept. In an essay in Public Culture, John Borneman (2002: 281) simply defined the term as "to render no longer opposed", but qualified this definition by adding that reconciliation should not be considered in terms of permanent peace or harmony. Instead, he argued that reconciliation involves foremost a structural departure from "violence", which in his view can only be accomplished through "listening", "witnessing" and "truth-telling". Since Borneman addressed reconciliation primarily in the context of violent ethnic conflicts towards the end of the 20th century, truth-telling formed a crucial component of his definition. Truth-telling involves more than just finding out who did what to whom, but is also about assessing a variety of truths in an inter-subjective, relational way, which Borneman (pp. 293-96) labelled as "listening". When carried out in public forums with skilled listeners, truth-telling might contribute to creating a community that can transcend the divisiveness and its associated revenge cycles which are common in ethnic conflicts. Truth-telling thus appears essential to restoring trust and to regaining a larger, more inclusive, moral community.

Listening to (or speaking) the truth after violent conflicts is essential for long-term reconciliation but, as has become obvious since the pathbreaking work of Michel Foucault $(1969,1980)$, truth is simultaneously and intrinsically related to institutional structures of power. Borneman (2002: 297300 ) embraces this dilemma by arguing that listening becomes effective only if complemented by a process of legal and institutional retribution. In contrast 
to listening, witnessing and truth-telling, legal retribution is concerned with sustaining the distinction between past and present, between wrong and right, in practice. Retribution does this by penalising those who took advantage of offences and other unlawful activities, as well as by vindicating the victims of the past. This type of retribution can only be realised within a system of legal accountability as embodied in the rule of law, which Borneman considers as the only alternative to revenge and rebounding violence.

Borneman (2002: 301) acknowledges that his vision of reconciliation may seem ambivalent since it is grounded not only within a legal framework that is imbued with politics and power but also in some sort of utopia based on the possibility of a departure from violence and injustice. In his view, however, this ambiguity is unavoidable because the basic task of reconciliation is paradoxical to the extent that it aims at facilitating an ongoing recuperation of a loss that is not recoupable. Listening is therefore an essential dimension of Borneman's understanding of reconciliation as it calls for a form of inter-subjectivity that is open to reflexive and relational knowledge, which also implies an often uncomfortable encounter with the Other, including the "enemy".

Borneman's idealistic perspective on reconciliation with its twin emphasis on listening and retribution evoked a number of critical responses in Public Culture. Steven Sampson (2003), for example, raised doubts about the supposedly dialogical nature of reconciliation and even accused Borneman of naiveté for his belief in dialogue. According to Sampson, Borneman's view of reconciliation is primarily about talk, which he argues is a peculiarly Western view of reconciliation. In addition, it assumes that the situation before conflict erupted was marked by peace, friendship and understanding, but he argues that these circumstances are in most cases simply the result of nostalgic theorising (p. 181).

The second point of critique raised by Sampson concerns Borneman's faith in the possibility of recovering the truth of what happened in the past. $\mathrm{He}$ contends that listening is not as simple as it seems since it also involves assessing, questioning and interpreting various accounts, "none of which are wholly true" (Sampson 2003: 183). Indeed, the "truth" is invariably controversial and therefore it is crucial to address the question how we are to deal with competing truths, a point which Borneman skirts around. For these reasons, Sampson proposed to replace the word reconciliation with the concept of coexistence, understood as "the absence of violence" (p. 182). Coexistence means mainly that parties that were previously enemies become oblivious to each other, simply ignoring each other. Whereas Borneman's state of reconciliation demands a dialogue of voice and response, coexistence is a social order that requires no listening. In the same vein, Laura Nader (2003) commented on Borneman's notion of reconciliation that "love is not enough" 
to confront the dark side of war if the practice of violence is to be put out of business. Peace means much more than disarmament and therefore she also argued that coexistence should be the primary aim of reconciliation.

Appropriately enough, given her role in bringing holocaust discourse to the forefront of New Zealand attention, Tariana Turia has more recently expressed her views on the subject of reconciliation. Having abandoned the New Zealand Labour Party in the aftermath of its actions on the foreshore and seabed issue (Charters and Erueti 2007), and having created a new political vehicle, the Maori Party, that gave Māori a much greater parliamentary voice after the 2005 elections, she commended Prime Minister Helen Clark for mentioning reconciliation in a speech outlining the government's programme for 2007. Yet, characteristically, she criticised her former leader for not taking a bold enough stance on reconciliation to encompass all levels of reconciliation and the "restoration of justice"- "economic, social, environmental, cultural" (Turia 2007).

\section{RECOGNITION AND REDISTRIBUTION}

From the discussion about reconciliation it emerges that the settlement of grievances about earlier events of different kinds is invariably represented in terms of two contrasting yet complementary interpretations. On the one hand, reconciliation may be understood in a broad sense as a process in which mistakes of the past are redressed and a new, more harmonious relationship is created between parties that were previously opposed. On the other hand, reconciliation may be interpreted in a more fundamental sense as a process that repairs the incompatibility of antithetical relations and interests between people. The question is, however, how these divergent interpretations of reconciliation may be combined and, by the same token, how incompatibility may be overcome.

This dilemma that is evoked by debates about reconciliation is often cast in terms of an inevitable discrepancy between the past and the present. Reconciliation usually starts from a reflection on historical injustices, but in many cases it simultaneously rehabilitates an ideology of progress into a future in which the past has been forgotten. Thus, mistakes of the past are no longer denied, but their recognition is almost immediately subordinated to the perpetuation of enlightenment values of development. These dynamics of reconciliation are particularly apparent in the context of apologies for wrongdoings in the past, such as in Australia. The acknowledgement of culpability in the past is linked to the trope of progress, to the further assimilation of Aborigines into mainstream Australian society, as in the subtext of Rudd's speech following his apology. This confirms that the continuing effects of the past in the present and the future are underestimated or, worse, rejected. A radical 
break with the past is paradoxically suggested in order to legitimise continuing effects of the past in the present (and the future). In such cases, reconciliation simply becomes another name for impunity (Sundar 2004: 150).

The ambiguity of reconciliation processes is most apparent in a postcolonial context. Here the challenge is to redress colonial grievances without extending colonial dominance beyond the reconciliation. In nation-states with indigenous minorities this ambiguity revolves around the reconciliation of indigenous collective rights with the protection of the human rights of individual citizens (Van Meij1 2006). In some situations, the rights of minority groupings may be accommodated within a setting dominated by others, but this type of reconciliation does not always do away with the pressure of the majority on the minority to abandon their cultural differences and claims to political autonomy (Kymlicka and Bashir 2008).

This dilemma of justice in a postcolonial situation has been expressed in terms of a disconnection between recognition and redistribution by the leading critical theorist Nancy Fraser (1995, Fraser and Honneth 2003). Fraser has identified the struggle for recognition as the paradigmatic form of political conflict in the late 20th century. She has argued that demands for recognition have displaced the struggle for socio-economic redistribution as the remedy for injustice in the modern age. Postmodern struggles about nationality, indigenous rights, identity, religion and gender are now so urgent that the question of recognition is impossible to ignore, especially in postcolonial or neo-colonial relations, but at the same time it would be incorrect to assume that distributive justice has lost its appeal. On the contrary, economic inequalities continue to grow as neoliberal forces promote corporate globalisation and weaken governance structures that previously enabled some redistribution between colonising and colonised countries or groupings. Under the new conditions, therefore, the question of distributive justice cannot be dismissed. In consequence, a view of justice is required in which claims for recognition will be reconciled with claims for egalitarian redistribution. This requires justice to be construed in such a way that it encompasses both distribution and recognition as two mutually irreducible but equally important dimensions (Van Meijl and Goldsmith 2003; see also Fowler 2009).

Fraser's argument that only a framework that integrates the two analytically distinct perspectives of distribution and recognition will grasp the imbrications of economic inequality and cultural differences in postcolonial circumstances has drawn much attention in many forums of discussion, but her rigorous separation of economics, culture and politics has also been criticised (Swanson 2005). Notwithstanding her intention to apply the conceptual distinction between economics and culture only in an analytical manner, her perspectival dualism regarding recognition and redistribution has been rejected as a 
mere reflection of a separation of the categories of culture and economics. Obviously, this is not acceptable, partly because neither economics nor culture can be understood in isolation from politics, and all three dimensions influence each other. The real challenge is to develop a conceptual framework in which the analytical distinctions between the dimensions of economics, politics and culture are transcended categorically. We hope that this issue will contribute to that aim.

\section{EXAMINING THE SETTLEMENT OF COLONIAL GRIEVANCES IN} THE PACIFIC

The substantive articles that follow this introductory essay demonstrate only three of the vast number of possible trajectories of colonialism and its aftermath in the Pacific. Our small number of cases highlights the risk of proposing general conclusions, especially in light of their stunning diversity. What do the tiny low island Polynesian microstate of Tuvalu, an isolated valley in the sprawling resource-rich Melanesian powerhouse of Papua New Guinea, and the largely urban European settler-dominated nation of New Zealand have in common that would allow us to generalise? It is not enough to say that they all demonstrate the lingering, even recurring, influence of colonial rule. What we might take from them, however, is that while the indigenous subjects of colonialism may warily accept, and even come to terms with, the system during some of its historical stages, any enduring accommodation is fraught with difficulties. The colonialists fail to live up to their responsibilities and their promises, whether those are, to put it very broadly and even simplistically, promises of protection (Tuvalu), wealth and development (PNG) or continued sovereignty (New Zealand).

In sum, the articles in this special issue explore the legacy of colonialism in contemporary Pacific societies and illustrate how complicated it is to resolve intricate and multifaceted problems that follow directly from a colonial history of neglect, dispossession and alienation. The traumatic disruption of indigenous societies resulting from contact with European colonisation usually had devastating consequences for the physical, psychological, social and cultural well-being of individuals, families and even whole societies, and these experiences are unmistakably transmitted over generations. As a corollary, colonial histories of loss and associated experiences of hurt will continue to characterise the memory, ethos and identity of peoples with a colonial history, to some extent even irrespective of apologies being offered, settlements taking place and circumstances changing, whether for better or worse. After all, the case-studies collected in this issue illustrate the paradox that any attempt to come to terms with colonial grievances inevitably takes place under circumstances that are fundamentally different from the past, 
which in turn generates new problems that themselves stem from colonialism as well as other factors. Furthermore, the settlement of colonial grievances may not only create new problems, but the perception of these problems might also continue to change as time moves on. For that reason, too, it is inherently difficult, if not impossible, to establish postcolonial justice definitively, at least in the foreseeable future. Instead, reconciliation will remain a goal that former colonisers and colonised must continue to negotiate.

\section{ACKNOWLEDGEMENTS}

The three papers is this issue were first presented along with a number of others in a workshop we convened at the European Society for Oceanists conference in 2005. We would like to thank all who participated in that workshop for their stimulating discussion. We are particularly grateful to those participants whose papers for a variety of reasons are not included here: Katarina Ferro, Marilyn Lashley, John Morton, Margaret Mutu, Frances Peters-Little, Carmen Petrosian-Husa, Ann Sullivan and Alexandra Wessel.

\section{REFERENCES}

Alexander, Jeffrey C., Ron Eyerman, Bernhard Giesen, Neil J. Smelser and Piotr Sztompka, 2004. Cultural Trauma and Collective Identity. Berkeley: University of California Press.

Augoustinos, Martha, Brianne Hastie and Monique Wright, 2011. Apologing for historical injustice: Emotion, truth and identity in political discourse. Discourse and Society, 22 (5): 507-31.

Bal, Mieke, Jonathan Crewe and Leo Spitzer (eds), 1999. Acts of Memory: Cultural Recall in the Present. Hanover: Dartmouth College and University Press of New England.

Barkan, Elazar and Ronald Bush (eds), 2002. Claiming the Stones, Naming the Bones: Cultural Property and the Negotiation of National and Ethnic Identity. Los Angeles: Getty Research Institute.

Barkan, Elazar and Alexander Karn (eds), 2006. Taking Wrongs Seriously: Apologies and Reconciliation. Stanford: Stanford University Press.

Bingham, William, 1996. The cultural genocide of the Northern Marianas in historical context. Umanidát, 4: 8-20.

Borneman, John, 2002. Reconciliation after ethnic cleansing: Listening, retribution, affiliation. Public Culture, 14 (2): 281-304.

Bushnell, O.A., 1993. The Gifts of Civilation: Germs and Genocide in Hawai ' $i$. Honolulu: University of Hawaii Press.

Busse, Mark, 2008. Museums and the things in them should be alive. International Journal of Cultural Property, 15 (2): 189-200.

Clark, Jeffrey, 2004. Environmental change, economic development, and emigration in Tuvalu. In V.S. Lockwood (ed.), Globalation and Culture Change in the Pacific Islands. Upper Saddle River: Pearson Education, pp. 260-72. 
De L'Estoile, Benoît, 2008. The past as it lives now: An anthropology of colonial legacies. Social Anthropology, 16 (3): 267-79.

Elkins, Caroline, and Susan Pedersen (eds), 2005. Settler Colonialism in the Twentieth Century: Projects, Practices, Legacies. New York: Routledge.

Foucault, Michel, 1966. Les mots et les choses: Une Archéologie des sciences humaines. Paris: Gallimard.

-1969. L'archéologie du savoir. Paris: Gallimard.

1980. Power/Knowledge. Edited by Colin Gordon. Brighton: Harvester.

Fowler, Bridget, 2009. The recognition/redistribution debate and Bourdieu's theory of practice: Problems of interpretation. Theory, Culture and Society, 26 (1): 144-56.

Fraser, Nancy, 1995. From redistribution to recognition? Dilemmas of justice in a 'post-socialist' age. New Left Review, 212 (July/August): 68-93.

Fraser, Nancy and Axel Honneth, 2003. Redistribution or Recognition? A PoliticalPhilosophical Exchange. Translated by Joel Golb, James Ingram and Christiane Wilke. London: Verso.

Fukuyama, Francis, 1992. The End of History and the Last Man. New York: Free Press.

2011. The Origins of Political Order: From Prehuman Times to the French Revolution. New York: Farrar, Straus and Giroux.

Gemes, Juno, 2008. Witnessing the apology: Photographic essay. Australian Aboriginal Studies, (1): 115-23

Gifford, Adam, 2000. Nga Korero o te Wa: A Monthly Summary of Maori News and Views from Throughout Aotearoa, 10 (12): 3.

Goldsmith, Michael, 2002. Maori assertions of indigeneity, post-colonial traumatic stress disorder, and holocaust denial. In E. Kolig and H. Mückler (eds), Politics of Indigeneity in the South Pacific: Recent Problems of Identity in Oceania. Hamburg: LIT, pp. 85-94.

Harris, Sandra, Karen Grainger and Louise Mullany, 2006. The pragmatics of political apologies. Discourse and Society, 17 (6): 715-37.

Huyssen, Andreas, 2000. Present pasts: Media, politics, amnesia. Public Culture, 12 (1): 21-38.

Kowal, Emma, 2008. The politics of the gap: Indigenous Australians, liberal multiculturalism, and the end of the self-determination era. American Anthropologist, 110 (3): 338-48.

Kymlicka, Will and Bashir Bashir (eds), 2008. The Politics of Reconciliation in Multicultural Societies. Oxford: Oxford University Press.

Lyotard, Jean-François, 1979. La condition postmoderne: Rapport sur le savoir. Paris: Éditions de Minuit.

Nader, Laura, 2003. Departures from violence: Love is not enough. Public Culture, 15 (1): 195-97.

New Zealand Herald, 31 August 2000.

New Zealand Herald, 8 September 2000.

NZWT (New Zealand Waitangi Tribunal), 1996. The Taranaki Report: Kaupapa Tautahi: WAI 143: Muru me te Raupatu. Wellington: GP Publications. 
Otto, Ton and Nicholas Thomas, 1997. Introduction. In T. Otto and N. Thomas (eds), Narratives of Nation in the South Pacific. Amsterdam: Harwood, pp. 1-13.

Rudd, Kevin, 2008. Apology to Australia's Indigenous Peoples. Canberra: House of Representatives, Hansard, 13 February 2008.

Salzman, Michael, 2005. The dynamics of cultural trauma: Implications for the Pacific nations. In A.J. Marsella, A.A. Austin, and B. Grant (eds), Social Change and Psychosocial Adaptation in the Pacific Islands: Cultures in Transition. New York: Springer, pp. 29-51.

Sampson, Steven, 2003. From reconciliation to coexistence. Public Culture, 15 (1): 181-86.

Short, Damien, 2008. Reconciliation and Colonial Power: Indigenous Rights in Australia. Aldershot: Ashgate.

Stein, Arlene, 1998. Whose memories? Whose victimhood? Contests for the holocaust frame in recent social movement discourse. Sociological Perspectives, 41 (3): 519-40.

Sundar, Nandini, 2004. Toward an anthropology of culpability. American Ethnologist, 31 (2):145-63.

Swanson, Jacinda, 2005. Recognition and redistribution: Rethinking culture and the economic. Theory, Culture and Society, 22 (4): 87-118.

Turia, Tariana, 2000a. Notes for speech, New Zealand Psychological Society Conference, Waikato University, Hamilton, 29 August.

2000b. A stress disorder. Mana, (36/ November): 64-65. 2007. Address in the Prime Minister's debate, Parliament, Auckland, 13 February.

Van Krieken, Robert, 2004. Rethinking cultural genocide: Aboriginal child removal and settler-colonial state formation. Oceania, 75 (2): 125-51.

Van Meijl, Toon, 2006. The paradox of indigenous rights: The controversy around the foreshore and the seabed in New Zealand. In E. Rata and R. Openshaw (eds), Public Policy and Ethnicity: The Politics of Ethnic Boundary Making. Basingstoke: Palgrave Macmillan, pp. 66-80.

Van Meijl, Toon (ed.), 2009. Pacific discourses about cultural heritage and its protection. International Journal of Cultural Property, 16 (3): 221-32, Special Issue.

Van Meij1, Toon and Michael Goldsmith, 2003. Introduction: Recognition, redistribution and reconciliation in postcolonial settler nation-states. Journal of the Polynesian Society, 112 (3): 205-18. [Special issue: Postcolonial Dilemmas: Reappraising Justice and Identity in New Zealand and Australia.]

Wing, John with Peter King, 2005. Genocide in West Papua? The Role of the Indonesian State Apparatus and Current Needs Assessment of the Papuan People. Sydney: West Papua Project, Centre for Peace and Conflict Studies, University of Sydney. Retrieved from the World Wide Web: http://sydney.edu. au/arts/peace_conflict/docs/WestPapuaGenocideRpt05.pdf 